foi empregue como colonos nas fazendas de café, mas o núcleo urbano, antes incipiente, não deixou também de se desenvolver no atendimento às necessidades comerciais, industriais e de serviços que a economia cafeeira requisitava (Truzzi, 2000).

Ano/Edição Ano XVI, no 47, set-dez/2003. São Paulo

\begin{tabular}{ll}
\hline Título & $\begin{array}{l}\text { Da acolhida solidária à hospitalidade comercializada: o } \\
\text { turismo na Chapada Diamantina }\end{array}$ \\
Autor/es & $\begin{array}{l}\text { Francisco Emanuel Matos Brito } \\
\text { Resumo }\end{array}$ \\
& $\begin{array}{l}\text { Neste artigo, além de realizamos uma breve retrospectiva } \\
\text { histórica sobre a viagem e o turismo, também abordamos as } \\
\text { tanto nos primórdios da viagem e a partir do advento do } \\
\text { turismo, quanto na análise de uma situação concreta, tomando } \\
\text { como exemplo a Chapada Diamantina. } \\
\text { Na sua conotação religiosa a acolhida dos visitantes por parte } \\
\text { dos hospedeiros se configurava num ato de bondade ou } \\
\text { caridade. Mas, com o passar do tempo e com as mudanças }\end{array}$ \\
& $\begin{array}{l}\text { ocasionadas nos costumes, alterações significativas se farão } \\
\text { presentes nos vínculos estabelecidos entre os visitantes e } \\
\text { visitados. Vale dizer que as viagens começaram sob a forma }\end{array}$ \\
de peregrinações e "todas as religiões estimularam as viagens \\
na crença de que são boas para a alma"(Zeldin, 1996, p.272).
\end{tabular}

\title{
TEMPORALIDADES E ESPAÇOS
}

Título Autor/es Resumo Ano/Edição
Tempos e espaços

José Guilherme Cantor Magnani

Editorial

Ano VI, no 15, jan-abril/1993. São Paulo 


$\begin{array}{ll}\text { Título } & \text { Entre o rural e o urbano } \\ \text { Autor/es } & \text { Maria Cristina Silva Costa } \\ \text { Resumo } & \text { Migrantes rurais em expressiva maioria, os trabalhadores rurais } \\ \text { temporários residentes em Ribeirão Preto/SP contam histórias } \\ \text { de vidas retirantes dos que, em outros tempos, encontraram } \\ \text { terra, trabalho e morada interligados e relacionados com } \\ \text { a família. sob formas diversas. Do espaço e tempo que a } \\ \text { memória reconstrói emergem as recordaçoses do roçado e da } \\ \text { criação de subsistência, incluídos nas relações tradicionais } \\ \text { de colonato, do "trabalho independente", da autonomia de } \\ \text { 'plantar na própria terra". Nostálgicos, confrontando com as } \\ \text { privações da vida atual, falam de um tempo de vida saciada, } \\ \text { em que "a gente comia bem, morava em casa melhor, de } \\ \text { tijolo, casa de fazenda". A reconstrução imaginária do passado } \\ \text { exclui conflitos c privações, seleciona atributos que alimentam } \\ \text { a saudade da vida farta, do trabalho recriado em liberdade } \\ \text { de "poder parar para descansar numa sombra e ouvir um } \\ \text { passarinho cantar". Os aspectos cooperativos e familiares do } \\ \text { trabalho, vínculos afetivos, solidariedade e autonomia são } \\ \text { enfatizados. } \\ \text { Ano VI, no 15, jan-abril/1993. São Paulo }\end{array}$


242 (Barreiras-Salvador), que, atualmente cortam a região. Verifica-se, então, a implantação do perímetro irrigado pela CODEVASF nos municípios de Barreiras e São Desidério, que atrairá as empresas da construção civil; a implantação de projetos de reflorestamento e de destilarias com vistas ao Pró-Álcool e, finalmente, mas não menos importante, ocorre a vinda de empresários rurais da zona cacaueira, de outras regiões do estado e fazendeiros pernambucanos que implantaram projetos agro-pecuários nas áreas de vale com recursos creditícios do FINOR, SUDENE e Banco do Nordeste.

Ano/Edição Ano VI, no 15, jan-abril/1993

\section{Título}

Autor/es

Resumo

Ano/Edição

Título

Autor/es

Resumo

\section{Representações da liberdade...}

\section{Lúcia Helena de Oliveira Cunha}

Dizer do tempo do pescador artesanal é. antes demais nada, aludir às temporalidades que regem a vida social - aos diferentes ritmos humanos que marcam a história em cada época e lugar. Ao contrário do que é comumente suposto no imaginário ocidental dominante, o tempo não é algo físico cronológico e linear -, posto pela ordem da natureza, como uma dimensão que se fixa de fora - por medidas externas -, independente dos homens. Como uma criação cultural, o tempo é, na verdade, imprimido, vivido e representado de modo peculiar em cada contexto histórico-social. Segundo observa Castoriadis, "cada sociedade tem sua maneira própria de viver o tempo, mas: cada sociedade é também uma maneira de fazer o tempo e de o fazer ser o que significa: uma maneira de se fazer ser como sociedade' 1982:243). Assim, a categoria tempo - inscrita na ordem social ou da cultura - consiste em um importante indicador da rede de relações sociais prevalecente numa determinada sociedade.

Ano VI, no 15, jan-abril/1993

\section{A cidade sem infância no universo pioneiro da soja}

Odette Carvalho de Lima Seabra; Sérgio Manuel Merêncio Martins

Este ensaio reporta-se a uma cidade formada em área de recente expansão da soja. Cidade sem infância, ou, o que equivale dizer, cidade que nasce adulta, porque inscrita na lógica reprodutiva do capital financeiro internacional. Trata-se do núcleo urbano de Chapadão do Sul, no estado do Mato Grosso do Sul, cuia ocupação, a partir do início dos anos 70 , é vivida por um movimento pioneiro 
de gaúchos. oriundos principalmente de municípios como ljuí, Erechim, Palmeira das Missões, Santo Augusto, entre outros. Famílias inteiras, grande parte delas de extração rural, lançaramse a esta terra de horizontes desmesurados $\mathrm{c}$ nela implantaram um mundo febril. Estes pioneiros se autodescrevem como desbravadores... e de fato o são.

Ano/Edição Ano VI, no 15, jan-abril/1993

Título

Autor/es

Resumo

Ano/Edição
As cidades dos bóias-frias: o desdobramento do poder e controle da empresa

\section{Maria Aparecida de Moraes Silva}

Nas últimas décadas, o processo de urbanização na região agrícola de Ribeirão Preto (São Paulo) tem-se caracterizado por um forte crescimento demográfico tanto das cidades médias como daquelas cognominadas cidades-dormitórios, habitadas por trabalhadores rurais, conhecidos como boias-frias. Estas últimas, além dos migrantes rurais da região, receberam. neste período, um contingente enorme de trabalhadores provenientes de ou Iras partes do país, principalmente do nordeste, norte do Paraná e Vale do Jequitinhonha (M. Gerais). Através dos dados estatísticos, tem-se observado que estas cidades tiveram um crescimento demográfico, em alguns casos, superior à média do Estado. nos últimos anos. O objetivo deste artigo não é o de se concentrar na explicação do processo de urbanização desta região. Propõe-se analisar as cidades habitadas pelos trabalhadores rurais como espaços sociais, isto é, como espaços socialmente diferenciados. Ano VI, no 15, jan-abril/1993

\section{TRABALHO}

Título

Autor/es

Resumo
Mineiros no corte da cana na Região de Ribeirão Preto (SP) José Giacomo Baccarin; José Jorge Gebara

Neste trabalho, procuramos estudar a migração sazonal para a região canavieira de Ribeirão Preto, de trabalhadores do Vale do Jequitinhonha. Verificamos suas condições de vida e trabalho, tanto na região de origem (o Vale), como na região de destino (a região de Ribeirão Preto). Comentamos também as 